\title{
Physiology of Crops and Weeds Under Biotic and Abiotic Stresses
}

\author{
Germani Concenço ${ }^{1}$, Ignacio Aspiazú ${ }^{2}$, Evander A. Ferreira ${ }^{3}$, \\ Leandro Galon ${ }^{4}$ and Alexandre F. da Silva ${ }^{5}$ \\ ${ }^{1}$ Embrapa Agropecuária Oeste, Dourados-MS \\ ${ }^{2}$ Universidade Estadual de Montes Claros-MG \\ ${ }^{3}$ UFVJM, Diamantina-MG \\ ${ }^{4}$ Universidade Federal do Pampa, Itaqui-RS \\ ${ }^{5}$ Embrapa Milho e Sorgo, Sete Lagoas-MG \\ Brazil
}

\section{Introduction}

The application of knowledge with strong physiological basis of crop yield, allied to genetic and environmental factors, is essential in developing proper practices for crop management aiming high yields (Floss, 2008). Several aspects determine the performance of a particular crop plant in a given environment, such as temperature, water availability, incidence of pests, plant genetics and management applied. Although it is virtually impossible to control all these factors, plant behavior can be assessed when submitted to different levels of these factors to understand how the responses of the plant to that given stress are formed (Radosevich et al., 2007; Gurevitch et al., 2009).

Population growth leads to an increasing demand for food, fibers and energy, and requires both expansion of the area for crops as well as higher crop yields. In both cases, one of the limiting factors is the occurrence of weed species. The high cost of human labor led farmers to choose weed control practices which allow reduction of the production costs (Silva et al., 2007). In the past, chemical management was used as the only method of weed control, but several problems led to the development of cultural methods as effective tools for lasting and low cost weed management.

More recently the physiology and ecology of crops and weed species gained increasing importance in the development of methods of weed control (Radosevich et al., 2007; Gurevitch et al., 2009). Several studies of competition between crops and weed species were conducted and the results of these studies are being applied at planning of integrated management practices such as crop rotation, succession, crop-livestock integration and winter crops as tools for suppressing weed occurrence (Severino, 2005; Ceccon, 2007). Most of these studies allow modeling the dynamics of weeds infestation in certain crops and optimizing the system as a whole, based in dry mass accumulation, plants height, number of tillers or branches, number of inflorescences and other directly measured variables (Galon et al., 2007; Fleck et al., 2008; Bianchi et al., 2010). 
On the other hand, there is still a big gap between physiological, high specialized studies and application of these results for practical everyday weed management inside crops. Weed biologists, mainly from under developed countries, often do not use physiological parameters in association to the directly measured variables as tools for supporting their findings. Basic research materials which support applied studies (Radosevich et al., 2007; Larcher, 2004; Gurevitch et al., 2009; Aliyev, 2010), propose changes to this scenario.

This chapter is proposed to present options involving the application of physiological parameters in studies of crop-weed competition, whether the chemical tool of weed control is present or not, highlighting examples of studies of the types of findings which could result from the use of physiological parameters in ecophysiological and competition studies.

\section{Weed species}

Elaborate a definition for "weed species" in agricultural terms was never easy. All the current concepts are based in the not desired occurrence of a plant species in a given time and place (Silva et al., 2007). A plant species can be considered a weed if its presence interferes in some way in a given situation. Therefore, no specific plant species can be considered essentially a weed, since this will depend on the place and moment this species is present for it to be considered harmful to the system - a weed. Even a crop plant, like corn, can be considered a weed if it is growing inside a soybean field, for example.

Weed species can be classified in terms of vegetative cycle, habitat or growth habit. But despite this, general features of these species are (1) high capacity of producing seeds and other reproductive structures; (2) seeds keep viability even under unfavorable conditions; (3) seeds capable of germinating and emerging from deep soil layers; (4) seeds dormancy, which allows a continuous and low percentage of germination; (5) alternative methods of propagation (rhizomes, stolons, bulbs, underground seeds); (6) mechanisms of seed dispersion (seeds with wings or hooks); (7) fast initial growth and development; and (8) seeds longevity (Silva et al., 2007).

\section{Chemical weed control}

The wide acceptance of chemical weed control with herbicides can be attributed to: (1) less demand of human labor; (2) efficient even under rainy seasons; (3) efficient in controlling weeds at the crop row with no damage to crop root system; (4) essential tool for no-till planting systems; (5) efficient in controlling vegetatively propagated weed species ; and (6) allows free decision about planting system (in rows, sowing) and crop row spacing (Silva et al., 2007).

It is important to consider, however, that a herbicide is a chemical molecule that should be correctly managed to avoid human intoxication as well as environmental contamination (Silva et al., 2007). The knowledge in plant physiology, chemical herbicide groups and technology of pesticide application is essential for the success of the chemical weed control (Floss, 2008). Surely there are risks involved at this method, but if they are known they can be avoided and controlled.

Chemical weed control should be applied as an auxiliary method. Efforts should be focused on the cultural method of weed management once it allows the best conditions for the development of crops while at the same time creating barriers for the proper development of seedlings of weed species (Silva et al., 2007; Floss, 2008). 
In addition, the application of herbicides will, as mandatory, cause some level of harm over the crops - from almost no harm to near total plant death. These impacts are sometimes not easily visible externally at the plant, but the physiological parameters would be imbalanced resulting in lower plant performance. Because of that, more susceptible parameters like the ones associated to the photosynthesis and water use of plants are essential tools for monitoring herbicide safety for crops.

\section{Competition between plant species}

Among several interpretations, "plant competition" essentially means a reduction in performance of a given plant species of importance, due to shared use of a limited available resource (Gurevitch et al., 2009). Competition between plants is different from the competition between animals. Due to the lack of mobility, the competition among plants apparently is passive, not being visible at the beginning of the development (Floss, 2008). It is known, however, that crops in general terms do not present high competitive ability against weed species, due to the genetic refinement they were submitted to increase the occurrence of desired productive features in detriment of aggressiveness (Silva et al., 2007).

According to Grime (1979), as cited in Silva et al. (2007), competition is established when neighboring plants use the same resources, and success in competition is strongly determined by the plant capacity to capture these resources. Thus, a good competitor has a high relative growth rate and can use the available resources quickly. However, Tilman (1980), cited in Silva et al. (2007), claims that competitive success is the ability to extract scarce resources and to tolerate this lack of resources - essentially to be more efficient in extracting and using a given resource. Therefore, in theory, a good competitor could be the species with least resource requirement (Radosevich et al., 2007).

In agricultural systems, both the crop and weeds grow together in the same area. As both groups usually demand similar environmental factors as water, light, nutrients and $\mathrm{CO}_{2}$, and usually these resources are not enough even for the crops, the competition is established. Under this situation, any strange plant which emerges at this area will share these limited resources, causing a reduction both in the volume produced by the crops, as well as in the quality of the harvested product (Floss, 2008). Radosevich et al. (2007) classified the environmental factors which determine plant growth in "resources" and "conditions".

Resources are the consumed factors such as water, $\mathrm{CO}_{2}$, nutrients and light, and the response of plants usually follows a standard curve: it is small if the resource is less available and maximum at the saturation point, usually declining again in case of excessive availability of the resource (e.g. toxicity due to excessive zinc availability in the soil). Conditions are factors not directly consumed, such as $\mathrm{pH}$ and soil density, although they influence directly plant ability in exploring the resources. However, plant competition will only be established when the demand of a given resource by a plant community surpasses the ability of the environment in supplying the demanded level of the given resource (Floss, 2008).

The competition between crops and weed species is critical for the crop in cases where the weed is established together or before the crop (Radosevich, 2007). However, if the crop presents similar competitive ability to the weeds and is capable of establishing itself first, it will cover the soil, preventing access of weeds to light (Silva et al., 2007) - which is one of the most determinant factors for plant establishment (Floss, 2008; Gurevitch et al., 2009). 
The competition can be established both among individuals of the same species (intraspecific competition), or among distinct plants (inter-specific competition). There is also the intra-plant competition, where distinct parts of the same plant (leaves, roots, flower buds) vie for photo-assimilates. Based on the previously exposed, in general terms the competitive process among plant species should be faced as follows (Silva et al., 2007):

- Competition is more serious in younger stages of development of the crop, e.g. at the first eight weeks for annual crops;

- Weed species morpho-physiologically similar to the crop are usually the most competitive in comparison to those which differ greatly from the crops;

- A moderate weed infestation in crop fields can be as harmful as a heavy infestation, depending on the moment these weeds are established;

- The competition is established for water, light, $\mathrm{CO}_{2}$, nutrients and physical space. Weed species can also exsudate to soil allelochemicals capable of inhibiting germination and/or growth of other plant species.

This chapter will be focused on competition for light, but competition for water and its related parameters will also be addressed as competition for these factors are related to photosynthesis rate or efficiency.

\section{The physiology of competition}

When plants are subjected to strong competition in the plant community, the physiological characteristics of growth and development are usually changed. This results in differences in the use of environmental resources, especially the water, which directly affects the availability of $\mathrm{CO}_{2}$ in leaf mesophyll and leaf temperature, therefore, the photosynthetic efficiency (Procópio et al., 2004b).

\subsection{Competition for light}

For some authors, competition for light is not as important as competition for water and nutrients. However, it should be considered that there is an interrelation among these factors (Silva et al., 2007). In fact, researchers are only starting to understand how the plant physiology is related to conditions of competition (Larcher, 2004). When the crop shades completely the soil, there is no competition for light between crops and weed species. For other authors, the genetic improvement of crops allowed these plants to be more efficient in intercepting and using light. As a consequence, plants of crop species present high Light Use Efficiency (LUE) when evaluated alone (Floss, 2008). Probably because of this, competition for light is often not considered in studies of plant competition.

Santos et al. (2003) evaluated the LUE of bean and soybean plants and of weed species Euphorbia heterophylla, Bidens pilosa and Desmodium tortuosum, and concluded that crops accumulated more dry mass per unit of light intercepted than any of the weeds studied. These authors also reported that, although the weeds were less efficient than crops in using light, they present high competitive ability in field conditions due to be more efficient in the extraction and use of other resources, like water and nutrients.

It is known that the competition for light is complex and its amplitude is influenced by the plant species, e.g. if the species is native to shaded or sunny environments and if it presents carbon metabolism of the type $\mathrm{C}_{3}, \mathrm{C}_{4}$ or CAM. The differences between these plant groups are based on the reactions that take place at the dark phase of photosynthesis (Floss, 2008; Gurevitch et al., 2009). 
It is common to imagine that $\mathrm{C}_{4}$ plants are always more efficient than $\mathrm{C}_{3}$ plants; however, this is true only under certain conditions (Silva et al., 2007). The $C_{4}$ plants demand higher levels of energy for producing photoassimilates, because they present two carboxilative systems, and thus need to recover two enzymes for a new photosynthetic cycle. It is known that the relation $\mathrm{CO}_{2}$ fixed/ATP/NADPH is 1:3:2 for $\mathrm{C}_{3}$ species and 1:5:2 for $\mathrm{C}_{4}$ species. This remarks the higher need of energy for photosynthesis in $\mathrm{C}_{4}$ plants. As all this energy comes from light, if the access to light is reduced, $\mathrm{C}_{4}$ plants will be less competitive than $\mathrm{C}_{3}$ species.

On the other hand, the enzyme responsible for carboxilation in $\mathrm{C}_{4}$ species presents some characteristics like high affinity for $\mathrm{CO}_{2}$; no oxygenase function; optimal performance at higher temperatures; and no saturation under high light availability. As a function of these and other features, when plants are under high temperatures, light availability and also temporary water deficit, $C_{4}$ species are capable of completely overcoming $C_{3}$ species, being able to accumulate twice the dry mass per unit of leaf area in the same time interval (Silva et al., 2007).

\subsection{Competition for water}

Plants are powerful pumps extracting water from the soil, and because of this in hot days it is common to see crops submitted to water deficit presenting some degree of wilting, while plants of some weed species are still completely turgid. Usually, the competition for water causes the plant to compete also for light and nutrients (Silva et al., 2007). Several factors influence the competitive ability of a plant in competing for water, highlighting the volume of soil explored (proportional to the volume of the root system), physiological characteristics of the plant, stomatal regulation, osmotic adjustment in roots and hydraulic conductivity capacity of the roots (Floss, 2008).

Some plant species are capable of using less water per unit of dry mass accumulated than others, because they are more efficient in the use of the water (Water Use Efficiency - WUE $=$ amount of dry mass accumulated as a function of water used at the same period). It is possible to infer that plants with higher WUE (more efficient in the use of water) are more productive when submitted to periods of limited water availability, as well as more competitive (Radosevich et al., 2007). However, some weed species may present distinct values of WUE throughout the cycle, being more competitive for water in certain stages of their development (Silva et al., 2007).

Differences in WUE are important in plant aggressiveness, although this is not the only mechanism allowing survival to water competition. The stomatal self-regulation, in terms of stomatal conductance, plays an important role in overcoming water deficit periods.

\subsection{Competition for $\mathrm{CO}_{2}$}

In relation to $\mathrm{CO}_{2}$, competitive aspects involving the availability of this gas are usually not considered. However, when the distinct carbon cycles presented by crops and weed species are detailed, it is possible to observe that the $\mathrm{CO}_{2}$ concentration in the leaf mesophyll, necessary for a given species to properly accumulate dry mass, is distinct. As the efficiency in capturing $\mathrm{CO}_{2}$ from the air is distinct between $\mathrm{C}_{3}$ and $\mathrm{C}_{4}$ species, and also the concentration of $\mathrm{CO}_{2}$ may vary inside a given mixed plant community, the availability of $\mathrm{CO}_{2}$ may be limiting for photosynthesis under competition, mainly for $\mathrm{C}_{3}$ plant species (Silva et al., 2007). 


\section{Characteristics related to the photosynthesis and water use efficiency}

The photosynthesis rate surely is one of the main processes responsible for high crop yields, but the liquid photosynthesis is a result of interaction among several processes, and each one of these processes, alone or in sets, may limit plant gain in terms of photoassimilates (Floss, 2008). The genetic variation among species and even among biotypes of the same species may shift the enzimatic mechanism and make a given species more capable than other in extracting or using efficiently a given environmental resource aiming to maximize its photosynthetic rate. Until recently, it was widely accepted that light affected indirectly the stomatal opening through the $\mathrm{CO}_{2}$ assimilation dependent on light - i.e., light increased the photosynthesis rate, which would reduce the internal $\mathrm{CO}_{2}$ concentration in the leaf and as a consequence the stomata would open. However, more accurate studies concluded that stomatal response is less connected to the internal $\mathrm{CO}_{2}$ concentration of the leaf than anticipated; most of the response to light in stomatal opening is direct, not mediated by $\mathrm{CO}_{2}$ (Sharkey \& Raschke, 1981).

Distinct light regimes, both in terms of quantity and composition, influence almost all physiological processes like photosynthesis and respiration rates, affecting also variables like plant height, fresh and dry mass and water content of the plant (Pystina \& Danilov, 2001). Water content, on the other hand, shifts both the stem length and leaf area of the plant, in a way to adapt the plant to the amount or quality of light intercepted (Aspiazú et al., 2008).

Interspecific and intraspecific plant competition affect the amount and the quality of the final product, as well as its efficiency in utilization of environmental resources (VanderZee \& Kennedy, 1983; Melo et al., 2006). This is noted when assessing physiological characteristics associated to photosynthesis, such as concentration of internal and external gases (Kirschbaum \& Pearcy, 1988), light composition and intensity (Merotto Jr. et al., 2009) and mass accumulation by plants under different conditions.

Although gas exchange capability by stomata is considered a main limitation for photosynthetic $\mathrm{CO}_{2}$ assimilation (Hutmacher \& Krieg, 1983), it is unlikely that gas exchange will limit the photosynthesis rate when interacting with other factors. However, photosynthetic rate is directly related to the photosynthetically active radiation (composition of light), to water availability and gas exchange (Naves-Barbiero et al., 2000). Plants have specific needs for light, predominantly in bands of red and blue (Messinger et al., 2006). When plants do not receive these wave lengths in a satisfactory manner, they need to adapt themselves in order to survive (Attridge, 1990). When under competition for light, the red and far-red ratio affected by shading is also important (Merotto Jr. et al., 2009) and influences photosynthetic efficiency (Da Matta et al., 2001).

The physiological parameters associated to photosynthesis rate and dynamics of water use in plant species will be presented, and on the following the application of these parameters in studies of plant competition (both in crops and weed species), and studies of herbicide toxicity to crops and forest trees will be discussed.

\subsection{Physiological parameters}

Table 1 presents the main physiological parameters evaluated by the equipment called Infra Red Gas Analyzer (IRGA). Details on the principles of measurements by this equipment, as well as cares to be taken to avoid reading errors, can be found in Dutton et al. (1988), Long \& Bernacchi (2003) and in the technical manual of the equipment. Please note that the parameters available vary among equipments from different manufacturers, as well as 


\begin{tabular}{|c|c|c|}
\hline Parameter & Usual Unit & Name and Description \\
\hline $\mathbf{A}$ & $\mu \mathrm{mol} \mathrm{m} \mathrm{m}^{-2} \mathrm{~s}^{-1}$ & $\begin{array}{l}\text { Photosynthesis rate - Rate of incorporation of } \\
\text { carbon molecules from the air into biomass. } \\
\text { Supplied by equipment. }\end{array}$ \\
\hline E & $\mathrm{mol} \mathrm{H}_{2} \mathrm{O} \mathrm{m}^{-2} \mathrm{~s}^{-1}$ & $\begin{array}{l}\text { Transpiration - Rate of water loss through stomata. } \\
\text { Supplied by equipment. }\end{array}$ \\
\hline Gs & $\mathrm{mol} \mathrm{m}^{-1} \mathrm{~s}^{-1}$ & $\begin{array}{l}\text { Stomatal conductance - Rate of passage of either water } \\
\text { vapor or carbon dioxide through the stomata. } \\
\text { Supplied by equipment. }\end{array}$ \\
\hline $\mathbf{C i}$ & $\mu \mathrm{mol} \mathrm{mol}-1$ & $\begin{array}{l}\text { Internal } \mathrm{CO}_{2} \text { concentration - Concentration of } \mathrm{CO}_{2} \text { in the } \\
\text { leaf mesophyll. Supplied by equipment. }\end{array}$ \\
\hline $\mathrm{E}_{\mathrm{an}}$ & mBar & $\begin{array}{l}\text { Vapor pressure at sub-stomatal chamber - Water pressure at } \\
\text { the sub-stomatal zone within the leaf. } \\
\text { Not supplied by some equipments. }\end{array}$ \\
\hline$\Delta \mathbf{C}$ & $\mu \mathrm{mol} \mathrm{mol}-1$ & $\begin{array}{l}\text { Carbon gradient - Gradient of } \mathrm{CO}_{2} \text { between the interior } \\
\text { and the exterior of the leaf. Usually not supplied by } \\
\text { equipment. May be calculated by the difference between } \\
\text { the } \mathrm{CO}_{2} \text { of reference (supplied by equipment) and } \\
\text { its concentration at the mesophyll } \\
\text { (Ci - supplied by equipment). }\end{array}$ \\
\hline $\mathbf{T}_{\text {leaf }}$ & ${ }^{\circ} \mathrm{C}$ & Leaf temperature - Supplied by equipment in ${ }^{\circ} \mathrm{C}$ or ${ }^{\circ} \mathrm{F}$. \\
\hline$\Delta \mathrm{T}$ & $\Delta{ }^{\circ} \mathrm{C}$ & $\begin{array}{l}\text { Temperature gradient - Not supplied by equipment. May } \\
\text { be calculated by the difference between the temperature } \\
\text { of the leaf (supplied by equipment) and the } \\
\text { environmental temperature (supplied by equipment). }\end{array}$ \\
\hline WUE & $\mu \mathrm{mol} \mathrm{CO} 2 \mathrm{~mol} \mathrm{H}_{2} \mathrm{O}^{-1}$ & $\begin{array}{l}\text { Water use efficiency - Describes the relation between the } \\
\text { rate of incorporation of } \mathrm{CO}_{2} \text { into biomass and the } \\
\text { amount of water lost at the same time interval. Usually } \\
\text { not supplied. May be calculated by dividing } \\
\text { photosynthesis (A) by transpiration (E). May be } \\
\text { presented in several distinct units. }\end{array}$ \\
\hline A/Gs & Curve* & $\begin{array}{l}\text { Intrinsic water use efficiency - Not widely used, but } \\
\text { describes a relation between the actual photosynthesis } \\
\text { rate and the stomatal conductance. The original units of } \\
\text { each parameter is maintained. }\end{array}$ \\
\hline $\mathrm{A} / \mathrm{Ci}$ & Curve* & $\begin{array}{l}\text { Photosynthesis } / \mathrm{CO}_{2} \text { relation - Describes the curve of } \\
\text { photosynthesis rate as the concentration of } \mathrm{CO}_{2} \text { within } \\
\text { the leaf is increased. The original units of each parameter } \\
\text { is maintained. }\end{array}$ \\
\hline
\end{tabular}

*These data should be represented as a graph showing the relation between variables as the concentration of one of them is increased; thus, the original units are maintained.

Table 1. Physiological parameters usually available when using an Infra Red Gas Analyzer (IRGA). Parameters available vary among manufacturers as well as among models of the same manufacturer. Some parameters are supplied by the equipment while others have to be calculated. 
among models of the same manufacturer. Some of them $\left(\Delta \mathrm{C}, \mathrm{T}_{\text {leaf }} \Delta \mathrm{T}\right.$ and WUE) are usually not automatically supplied, but may be easily calculated based on parameters supplied by the equipment. The measuring units of the parameters also vary, and the most common units were adopted at Table 1. Water use efficiency (WUE) have several interpretations and may be presented in several different units, for distinct purposes. For a more comprehensive overview of this parameter, please consult Tambuci et al. (2011).

\subsection{Photosynthesis}

The photosynthesis (A) and thus the respiration, depend upon a constant flux of $\mathrm{CO}_{2}$ and $\mathrm{O}_{2}$ in and out of the cell; this free flux is a function of the concentration of $\mathrm{CO}_{2}(\mathrm{Ci})$ and $\mathrm{O}_{2}$ at the intercellular spaces, which depend on the stomatal opening, major controller of the gas flux through stomata (Taylor Jr. \& Gunderson, 1986; Messinger et al., 2006). This is mainly controlled by the turgescence both of the guard cells (which control stomatal opening) as well as by the epidermic cells at the stomata (Humble \& Hsiao, 1970). A low water potential will promote reduction in stomatal opening and reduce the leaf conductance, inhibiting photosynthesis and also the respiration (Attridge, 1990), and increasing the gradient of $\mathrm{CO}_{2}$ concentration between the leaf mesophyll and the exterior of the leaf $(\Delta \mathrm{C})$.

\subsection{Water use efficiency}

When plants are studied in terms of the efficiency they present when using water, the parameters stomatal conductance of water vapor (Gs), vapor pressure at the sub-stomatal chamber $\left(E_{a n}\right)$, transpiratory rate (E) and water use efficiency (WUE) should be considered. The WUE is obtained by the relation between $\mathrm{CO}_{2}$ incorporated in the plant and the amount of water lost by transpiration during the same period (Gurevitch et al., 2009). The more efficient water use is directly related to the photosynthetic efficiency as well as the dynamics of stomatal opening, because while the plant absorbs $\mathrm{CO}_{2}$ for the photosynthesis, it also loses water to the atmosphere by transpiration, in rates that depend on the potential gradient between the interior and the exterior of the leaf (Floss, 2008). Water exchange also allows the plant to keep adequate temperature levels, which can be evaluated by the leaf temperature $\left(\mathrm{T}_{\text {leaf }}\right)$, as well as by the difference between the leaf temperature and the temperature of the air surrounding the leaf $(\Delta \mathrm{T})$.

\section{Physiology of crops}

\subsection{Sugarcane}

Control of weed species is a mandatory practice which should be applied in sugarcane fields, and among the control methods available, the chemical is usually the most widely adopted on this crop. The reasons for that are (1) the big size of the sugarcane fields; (2) higher cost of the other control methods; (3) high efficiency of the chemical method; and (4) speed of the method.

There is a very limited knowledge about the impact of the application of herbicides on the physiology of crops. According to Azania et al. (2005), the application of late postemergence herbicides in sugarcane fields may result in high toxicity to the crop, limiting the yield. These authors attribute this to physiological changes in sugarcane plants which would result in negative effects, also on the quality of the harvest. 
Galon et al. (2010) studied the following herbicides, applied over several sugarcane genotypes: ametryn - $2.000 \mathrm{~g} \mathrm{ha}^{-1}$; trifloxysulfuron-sodium - 22,5 $\mathrm{g} \mathrm{ha}^{-1}$; and a commercial mixture containing ametryn + trifloxysulfuron-sodium at $1.463+37,0 \mathrm{~g} \mathrm{ha}^{-1}$, respectively. Treatments were compared against a check with no herbicide. The results are summarized in Table 2.

\begin{tabular}{|c|c|c|c|c|c|c|}
\hline \multirow{2}{*}{ Treatment } & \multicolumn{6}{|c|}{ Sugarcane Genotype } \\
\hline & RB72454 & RB835486 & RB855113 & RB867515 & RB947520 & SP801816 \\
\hline & \multicolumn{6}{|c|}{ Shoot Dry Mass (g plant ${ }^{-1}$ ) } \\
\hline TC & A 5,77 a & A 5,46 a & A 4,93 a & A 5,02 a & A 5,02 a & B 2,46 a \\
\hline HA & B $2,83 \mathrm{~b}$ & B 3,69 ab & B $2,89 \mathrm{~b}$ & A 5,97 a & B $3,38 \mathrm{ab}$ & B 3,63 a \\
\hline HB & A $5,21 \mathrm{ab}$ & B $2,81 \mathrm{~b}$ & B 3,81 ab & B $2,99 \mathrm{~b}$ & B $2,03 \mathrm{~b}$ & B 2,30 a \\
\hline \multirow[t]{2}{*}{ HC } & A $2,90 \mathrm{~b}$ & A $1,99 \mathrm{~b}$ & A $2,46 \mathrm{ab}$ & A $2,09 \mathrm{~b}$ & A $1,66 \mathrm{~b}$ & A $1,30 \mathrm{a}$ \\
\hline & \multicolumn{6}{|c|}{ Consumed $\mathrm{CO}_{2}-\Delta \mathrm{C}(\mu \mathrm{mol} \mathrm{mol}-1)$} \\
\hline$\overline{\mathrm{TC}}$ & A $124 \mathrm{ab}$ & AB 149 a & B 120 a & AB $139 \mathrm{a}$ & A 177 a & B 117 a \\
\hline HA & A 109 b & B 75 c & $\mathrm{AB} 105 \mathrm{~b}$ & AB $91 \mathrm{~b}$ & $\mathrm{AB} 102 \mathrm{~b}$ & A 110 a \\
\hline HB & AB $119 \mathrm{ab}$ & B $106 \mathrm{~b}$ & $\mathrm{AB} 114 \mathrm{ab}$ & AB $118 \mathrm{ab}$ & A $144 \mathrm{ab}$ & B 108 a \\
\hline \multirow[t]{2}{*}{ HC } & A $131 \mathrm{a}$ & A $107 \mathrm{~b}$ & $\mathrm{AB} 112 \mathrm{ab}$ & A 95 b & A 118 b & A $111 \mathrm{a}$ \\
\hline & \multicolumn{6}{|c|}{ Internal $\mathrm{CO}_{2}$ Concentration - $\mathrm{Ci}\left(\mu \mathrm{mol} \mathrm{mol}{ }^{-1}\right)$} \\
\hline TC & AB $102 \mathrm{a}$ & A 177 a & AB $104 \mathrm{~b}$ & $\mathrm{AB} 123 \mathrm{~b}$ & B $68 \mathrm{c}$ & $\mathrm{AB} 120 \mathrm{~b}$ \\
\hline HA & A 165 a & A $136 \mathrm{ab}$ & A 169 a & A 178 a & A 134 a & A 157 a \\
\hline HB & AB $126 \mathrm{ab}$ & $\mathrm{AB} 127 \mathrm{ab}$ & AB $128 \mathrm{ab}$ & $\mathrm{AB} 114 \mathrm{~b}$ & B 88 b & A $137 \mathrm{ab}$ \\
\hline \multirow[t]{2}{*}{ HC } & $\mathrm{AB} 146 \mathrm{ab}$ & B 87,7 b & AB $125 \mathrm{ab}$ & A 179 a & $\mathrm{AB} 145 \mathrm{a}$ & A 158 a \\
\hline & \multicolumn{6}{|c|}{ Photosynthesis Rate $\left(\mu \mathrm{mol} \mathrm{m} \mathrm{m}^{-2} \mathrm{~s}^{-1}\right)$} \\
\hline TC & $\mathrm{AB} 45,1 \mathrm{a}$ & $\mathrm{AB} 51,2 \mathrm{a}$ & B 41,3 a & $\mathrm{AB} 47,9 \mathrm{a}$ & A 60,7 a & $\mathrm{AB} 48,0 \mathrm{a}$ \\
\hline HA & A $37,5 \mathrm{~b}$ & B 25,8 b & A 36,1 a & B 28,9 b & A $37,0 \mathrm{~b}$ & A $37,3 \mathrm{~b}$ \\
\hline HB & B $41,1 \mathrm{ab}$ & B $36,6 \mathrm{ab}$ & B 38,9 a & B $40,3 \mathrm{ab}$ & A $49,5 \mathrm{ab}$ & B $38,8 \mathrm{~b}$ \\
\hline $\mathrm{HC}$ & A $42,1 \mathrm{ab}$ & A $36,4 \mathrm{ab}$ & A 38,4 a & B $32,8 \mathrm{~b}$ & A 40,5 b & A $40,1 \mathrm{~b}$ \\
\hline
\end{tabular}

Table 2. Physiological variables evaluated in sugarcane genotypes as a function of herbicide treatment. TC: control with no herbicide; HA: ametryn at $2.000 \mathrm{~g}^{-1} \mathrm{a}^{-1}$ a.i.; HB:

trifloxysulfuron-sodium at 22,5 $\mathrm{g}^{-1}$ a.i.; HC: ametryn + trifloxysulfuron-sodium at $1.463+$ $37,0 \mathrm{~g} \mathrm{ha}^{-1}$ a.i. Means followed by the same letter at the column, inside each variable, are not different by the DMRT test at 5\% probability. Source: adapted from Galon et al. (2010).

In general terms, the $\mathrm{CO}_{2}$ consumed by photosynthesis $(\Delta \mathrm{C})$ was smaller in treatments including the herbicide ametryn. There were also remarkable differences between genotypes. The $\Delta \mathrm{C}$ is directly related to the photosynthesis rate of the plant by the time of the evaluation. In this situation, it is possible to observe that the genotypes RB72454 and SP80-1816 were less susceptible to ametryn than the other genotypes.

The concentration of $\mathrm{CO}_{2}$ within the leaf $(\mathrm{Ci})$ was affected by the herbicide treatments, being also observed once more differences between genotypes. As expected, this parameter presented, in general terms, opposite behavior in comparison to $\Delta \mathrm{C}$. The application of the herbicide ametryn, a photosynthesis II (PSII) inhibitor, resulted in higher concentrations of $\mathrm{CO}_{2}$ within the leaf, once the photosynthesis of the genotypes under application of this herbicide was more severely affected. The $\mathrm{CO}_{2}$ concentration within the leaf was around $50 \%$ higher in treatments involving ametryn in comparison to the control treatment with no 
herbicide. Trifloxysulfuron-sodium also caused changes in $\mathrm{Ci}$, but not at the same magnitude of ametryn.

In general terms, the photosynthesis rate (A) observed at the treatment with trifloxysulfuron alone was similar to the control with no herbicide. On the same way treatments involving the PSII inhibitor presented photosynthesis rate inferior to rates observed at the control treatment. When considering the treatment containing ametryn + trifloxysulfuron, it was possible to highlight the genotype RB947520.

The authors highlight that, even the damages caused by ametryn being more easily identified by evaluating parameters associated to the photosynthesis, variations due to the application of trifloxysulfuron-sodium were also detectable by changes in these parameters by using an Infra Red Gas Analyzer (IRGA). In other words, herbicidal damage on crops can be effectively quantified by evaluating direct and indirect damage to the photosynthetic route. Furthermore, the accumulation of dry mass did not correlate directly with most of the studied physiological parameters, because plant growth is a result of biomass accumulation since the emergence until the moment of the evaluation. In this way, the authors remark the importance of evaluating both types of variables, physiological and biomass/growth related, before concluding about the efficacy or impact of a given herbicide treatment. In addition, the authors remark the existence of differences among genotypes in terms of susceptibility to herbicides, which were effectively identified by physiological parameters.

\subsection{Cassava}

Several factors have contributed to the low productivity of cassava in under-developed countries, being the inadequate management of weeds one of the most important. Usually, cassava producers believe that this crop is rustic and there is no need to worry too much about weed control (Albuquerque, 2008). However, the competition between weeds and cassava can affect its production in quantitative and qualitative ways (Aspiazú et al., 2010a, 2010b). This competition alters the efficiency of use of environmental resources such as water, light, nutrients and space among species that occupy the same ecological niche (Melo et al., 2006; Floss, 2008).

Aspiazú et al. (2010b) studied the physiological interactions of cassava with three weed species in order to determine the mechanism the crop plants used to overcome the stress imposed by weed competition. One cassava plant was submitted to competition with one of these weed species: Bidens pilosa (three plants $\mathrm{m}^{-2}$ ), Brachiaria plantaginea (six plants $\mathrm{m}^{-2}$ ) or Commelina benghalensis (three plants $\mathrm{m}^{-2}$ ).

Cassava plants grown free of competition showed greater leaf internal $\mathrm{CO}_{2}$ concentration (Ci) than when competing with weeds (Table 3). Lower $\mathrm{CO}_{2}$ concentrations in leaves were observed when cassava plants were grown under competition with $C$. benghalensis. The highest values for $\mathrm{Ci}$ observed in cassava plants were when under competition with $B$. pilosa or B. plantaginea, if compared to $C$. benghalensis. That can be attributed to the accelerated plant metabolism as a way to increase growth rate and escape shading caused by weeds, as will be further detailed. It is believed that under these conditions, where lower Ci occurs, $\mathrm{CO}_{2}$ was consumed due to the increase at metabolic rate.

Studies conducted by some researchers showed that responses to changes in Red:Far Red (R:Fr) ratios occur before the mutual shading among neighbors. Based on these studies, it was proposed that the Far Red radiation, which is reflected by adjacent leaves, is a means of early detection that signals the imminence of competition during canopy development 
(Ballaré et al., 1990; Merotto Jr. et al., 2009; Aspiazú et al., 2010b). In addition, some species are capable of recognizing others by the amount of radiation reflected in each wave length essentially, the composition of the light reflected (Larcher, 2004; Aspiazú et al., 2010b).

\begin{tabular}{|c|c|c|c|c|}
\hline Treatment & $\begin{array}{c}\mathrm{Ci} \\
\left(\mu \mathrm{mol} \mathrm{mol}^{-1}\right)\end{array}$ & $\begin{array}{c}\Delta \mathrm{C} \\
(\mu \mathrm{mol} \mathrm{mol}-1)\end{array}$ & $\begin{array}{l}\mathrm{T}_{\text {leaf }} \\
\left({ }^{\circ} \mathrm{C}\right)\end{array}$ & $\begin{array}{c}\mathrm{A} \\
\left(\mu \mathrm{mol} \mathrm{m} \mathrm{m}^{-2} \mathrm{~s}^{-1}\right)\end{array}$ \\
\hline Cassava & $295,7 \mathrm{a}$ & $14,43 \mathrm{~b}$ & $32,1 \mathrm{~b}$ & $5,71 \mathrm{~b}$ \\
\hline Cassava $\times$ B. pilosa & $256,4 \mathrm{~b}$ & $12,73 \mathrm{~b}$ & $33,6 \mathrm{ab}$ & $5,17 \mathrm{~b}$ \\
\hline Cassava $\times C$. benghalensis & $232,3 \mathrm{c}$ & $19,60 \mathrm{a}$ & $35,1 \mathrm{a}$ & $7,32 \mathrm{a}$ \\
\hline Cassava $\times$ B. plantaginea & $266,9 \mathrm{~b}$ & $14,50 \mathrm{~b}$ & $33,6 \mathrm{ab}$ & $5,93 \mathrm{~b}$ \\
\hline CV (\%) & 10,0 & 19,4 & 3,6 & 15,2 \\
\hline
\end{tabular}

Table 3. Parameters associated to the photosynthesis of cassava plants 60 days after emergence, as a function of the weed species with whom cassava plants were under competition. Means followed by the same letter at the column, are not different by the DMRT test at 5\% probability. Source: Aspiazú et al. (2010b).

It was probably what happened when cassava plants competed with $C$. benghalensis; the presence of this slow growth, poor competitive weed species might have been simply enough to increase cassava metabolism aiming to avoid the imposition of future competition.

The authors also remark that the consumption of $\mathrm{CO}_{2}(\Delta \mathrm{C})$ increased proportionally to the decrease of $\mathrm{Ci}$. When the three weeds were compared, $\mathrm{C}$. benghalensis was the one that most increased the $\Delta \mathrm{C}$ of cassava, because there was a higher gradient between the internal and the external sides of the cassava leaves - this may indicate accelerated plant metabolism.

Cassava leaves temperature was higher when under competition with $C$. benghalensis, mainly due to the stimulus in metabolism caused by the presence of the weed, and due to the low competition exerted, or simply due to the changing of the quality of light, which allowed cassava plants to recognize the species of weed (Radosevich et al., 2007; Larcher, 2004). The competition-free control indicates the metabolic rate usual to cassava plants when free of competition. In this situation, plant growth becomes more balanced, distributing photoassimilates proportionally between shoots and roots, which is not the case when under competition (Radosevich et al., 2007).

The difference between leaf temperature and the air around it $(\Delta \mathrm{T})$ is commonly only 1 or 2 ${ }^{\circ} \mathrm{C}$, but in extreme cases it may exceed $5{ }^{\circ} \mathrm{C}$ (Attridge, 1990). Cassava plants under competition with B. pilosa or B. plantaginea stayed half way compared to the ones observed in weed-free control, and at treatment under competition with $C$. benghalensis. This indicates that these weeds were able to prevent cassava from reacting adequately to the imposition of competition, probably by limiting crop access to appropriate levels of a given resource, such as light or water, for example.

The photosynthetic rate was also higher for cassava plants under competition with $C$. benghalensis, when compared to other treatments. Photosynthetic rate of cassava under competition with $C$. benghalensis was $7,32 \mu \mathrm{mol} \mathrm{m} \mathrm{m}^{-2} \mathrm{~s}^{-1} \mathrm{CO}_{2}$, while for the average of the remaining treatments was $5,50 \mu \mathrm{mol} \mathrm{m}^{-2} \mathrm{~s}^{-1} \mathrm{CO}_{2}$. The radiation balance and composition on the plant when in competition or shading, combined with carbohydrate level in leaves, may increase respiratory rate directly or through alternative pathways associated with the respiratory chain (Pystina \& Danilov, 2001). This could make photosynthesis balance even 
smaller and reduce the ability of the plant to accumulate mass. The interaction between measured parameters is presented at Table 4.

\begin{tabular}{lcccc}
\hline & $\begin{array}{c}\mathbf{C i} \\
(\mu \mathrm{mol} \mathrm{mol}-\mathbf{1})\end{array}$ & $\begin{array}{c}\Delta \mathbf{C} \\
\left(\mu \mathrm{mol} \mathrm{mol}^{-1}\right)\end{array}$ & $\begin{array}{c}\mathbf{T}_{\text {leaf }} \\
\left({ }^{\circ} \mathbf{C}\right)\end{array}$ & $\begin{array}{c}\mathbf{A} \\
\left(\mu \mathrm{mol} \mathrm{m}^{-2} \mathbf{~ s}^{-1}\right)\end{array}$ \\
\hline $\mathbf{C i}$ & 1 & - & - & - \\
$\Delta \mathbf{C}$ & $-0,60^{*}$ & 1 & - & - \\
$\mathbf{T}_{\text {leaf }}$ & $-0,53$ & 0,34 & 1 & - \\
$\mathbf{A}$ & $-0,60^{*}$ & $0,96^{*}$ & 0,37 & 1 \\
\hline
\end{tabular}

* = significant at $5 \%$ of probability.

Table 4. Pearson linear correlation matrix as a function of the parameters associated to the photosynthesis of cassava plants grown alone or under competition with weed species, evaluated 60 days after emergence. Source: Aspiazú et al. (2010b).

In terms of parameters associated to the water use efficiency, the stomatal conductance (Gs) of cassava plants in coexistence with B. pilosa was inferior only to the treatment where cassava was grown alone (Table 5).

\begin{tabular}{|c|c|c|c|c|}
\hline Treatment & $\begin{array}{c}\mathrm{E} \\
\left(\mathrm{mol} \mathrm{H}_{2} \mathrm{O} \mathrm{m}^{-2} \mathrm{~s}^{-1}\right)\end{array}$ & $\begin{array}{c}\mathrm{Gs} \\
\left(\mathrm{mol} \mathrm{m}^{-1} \mathrm{~s}^{-1}\right)\end{array}$ & $\underset{(m b a r)}{E_{a n}}$ & $\begin{array}{c}\text { WUE } \\
\left(\mu \mathrm{mol} \mathrm{CO}{ }_{2}\right. \\
\left.\text { mol-1 }^{-1} \mathrm{H}_{2} \mathrm{O}\right)\end{array}$ \\
\hline Cassava & $3,57 \mathrm{a}$ & $0,13 \mathrm{a}$ & $22,40 \mathrm{a}$ & $1,81 \mathrm{~b}$ \\
\hline Cassava $\times$ B. pilosa & $2,31 \mathrm{c}$ & $0,07 \mathrm{~b}$ & $21,03 \mathrm{a}$ & $2,26 \mathrm{a}$ \\
\hline Cassava $\times C$. benghalensis & $3,69 \mathrm{a}$ & $0,11 \mathrm{ab}$ & 24,57 a & $1,98 \mathrm{ab}$ \\
\hline Cassava $\times$ B. plantaginea & $3,15 b$ & $0,12 \mathrm{ab}$ & $23,47 \mathrm{a}$ & $1,90 \mathrm{ab}$ \\
\hline CV (\%) & 19,7 & 24,40 & 6,6 & 9,8 \\
\hline
\end{tabular}

Table 5. Parameters associated to the water use of cassava plants 60 days after emergence, as a function of the weed species with whom cassava plants were under competition.

Means followed by the same letter at the column, are not different by the DMRT test at 5\% probability. Source: Aspiazú et al. (2010a).

Vapor pressure in the substomatal cavity of the cassava leaves $\left(E_{a n}\right)$ did not change in function of the competition between cassava and any of the weed species (Table 5). In Table 6, a high correlation between $\mathrm{E}$ and $\mathrm{E}_{\mathrm{an}}$ can be observed, although the latter was not modified in function of the species with which cassava competed. In this case, the changes in Gs can be attributed to factors not related to cassava plants, such as availability of soil water or wind speed, factors that can be changed by the presence of weeds.

The transpiration rate (E) was dependent on the weed species with which the cassava plant competed, being superior for the control free of weeds and for the cassava plant which competed with C. benghalensis (Table 5). This supports the considered hypothesis by the authors that $C$. benghalensis does not show a good competitive ability for light, because the crop had higher leaf temperature (Table 3) and higher transpiration rate (Table 5) when competing with this species, which indicates high metabolic rate and accelerated growth due to recognition of imposition of competition before it was actually established. The interactions between parameters associated to the water use are presented at Table 6 . 


\begin{tabular}{|c|c|c|c|c|}
\hline & $\begin{array}{c}\mathrm{E} \\
\left(\mathrm{mol} \mathrm{H} \mathrm{O}_{2} \mathrm{~m}^{-2} \mathrm{~s}^{-1}\right)\end{array}$ & $\begin{array}{c}\mathrm{Gs} \\
\left(\mathrm{mol} \mathrm{m}^{-1} \mathrm{~s}^{-1}\right)\end{array}$ & $\begin{array}{c}\mathrm{E}_{\mathrm{an}} \\
(\mathrm{mbar})\end{array}$ & $\begin{array}{c}\text { WUE } \\
\left(\mu \mathrm{mol} \mathrm{CO} \mathrm{mol} \mathrm{H}_{2} \mathrm{O}^{-1}\right)\end{array}$ \\
\hline $\bar{E}$ & 1 & 0,72 * & 0,87 * & $-0,26$ \\
\hline Gs & - & 1 & 0,49 & $-0,30$ \\
\hline Ean & - & - & 1 & $-0,09$ \\
\hline WUE & - & - & - & 1 \\
\hline
\end{tabular}

* = significant at $5 \%$ of probability.

Table 6. Pearson linear correlation matrix as a function of the parameters associated to the water use of cassava plants grown alone or under competition with weed species, evaluated 60 days after emergence. Source: Aspiazú et al. (2010a).

The photosynthetic characteristics of cassava were influenced by its competition with $B$. pilosa and B. plantaginea. The authors noticed that cassava plants are affected by these species especially concerning competition for light and water. However, there were no negative effects when cassava plants competed with $C$. benghalensis. This species seems to rather affect the composition of light by reflecting peculiar spectrum of specific wavelengths, which allows cassava plants to anticipate the imposition of competition even before they get to harmful levels.

\subsection{Eucalyptus}

The management of weed species in Eucalyptus plantations is based both on mechanical and chemical methods (Machado et al., 2010). When using the chemical method, the main active ingredient applied is the glyphosate, due to several advantages (Tuffi Santos et al., 2010). As this is a non selective herbicide, it is applied between plant rows, avoiding contact with the Eucalyptus plants, which could result in lower growth rates and eventually plant death (Tuffi Santos et al., 2010).

The possibility of severe damage for Eucalyptus by the application of glyphosate instigated the conduction of several researches involving the concept of "simulated drift". However, there are just a few researches in Brazil aiming at the physiological implications of glyphosate application in Eucalyptus plantations. In a pioneer study, Machado et al. (2010) modeled the impact of the herbicide glyphosate over clones of Eucalyptus grandis and E. urophylla. These authors were not able to identify differences in susceptibility among clones, but were able to characterize relatively well the behavior of physiological parameters in Eucaliptus under application of glyphosate. Four doses of glyphosate (43,2; 86,2; 129,6; and $172,8 \mathrm{~g} \mathrm{ha}^{-1}$ of the commercial formulation containing $360 \mathrm{~g} \mathrm{~L}^{-1}$ of the acid equivalent of glyphosate) were applied on two clones of each species when plants were around $40 \mathrm{~cm}$ height. The main results are synthesized in Figure 1.

When the photosynthesis rate was analyzed as a function of herbicide doses, there was no change seven days after application $\left(18,49 \mu \mathrm{mol} \mathrm{m}^{-2} \mathrm{~s}^{-1}\right)$. However, 21 days after application (DAA) the photosynthesis was reduced as the dose of the herbicide increased (Figure 1). At the higher herbicide doses, there was a proportional increasing in toxicity to the plants of Eucalyptus which caused leaf abscission, thus reducing the leaf area available for photosynthesis. The stomatal conductance (Gs) did not differ among herbicide doses 7 DAA, but it was reduced as the dose was increased at the evaluation of 21 DAA. According to the authors, this is due to the slow action of the glyphosate which usually causes most of the damage between 9 and 15 DAA.

In the same way of A and Gs, differences in transpiration (E) were not observed 7 DAA with increasing at the dose of glyphosate, but these differences were reported 21 DAA of the 
herbicide. The water use efficiency (WUE), however, was affected by increasing doses of the herbicide at the two evaluations (Figure 1), although these differences were more drastic 21 DAA. According to the authors, these differences in WUE are due at least in part to the reduction observed at the photosynthesis rate, which also resulted in smaller dry mass accumulation.
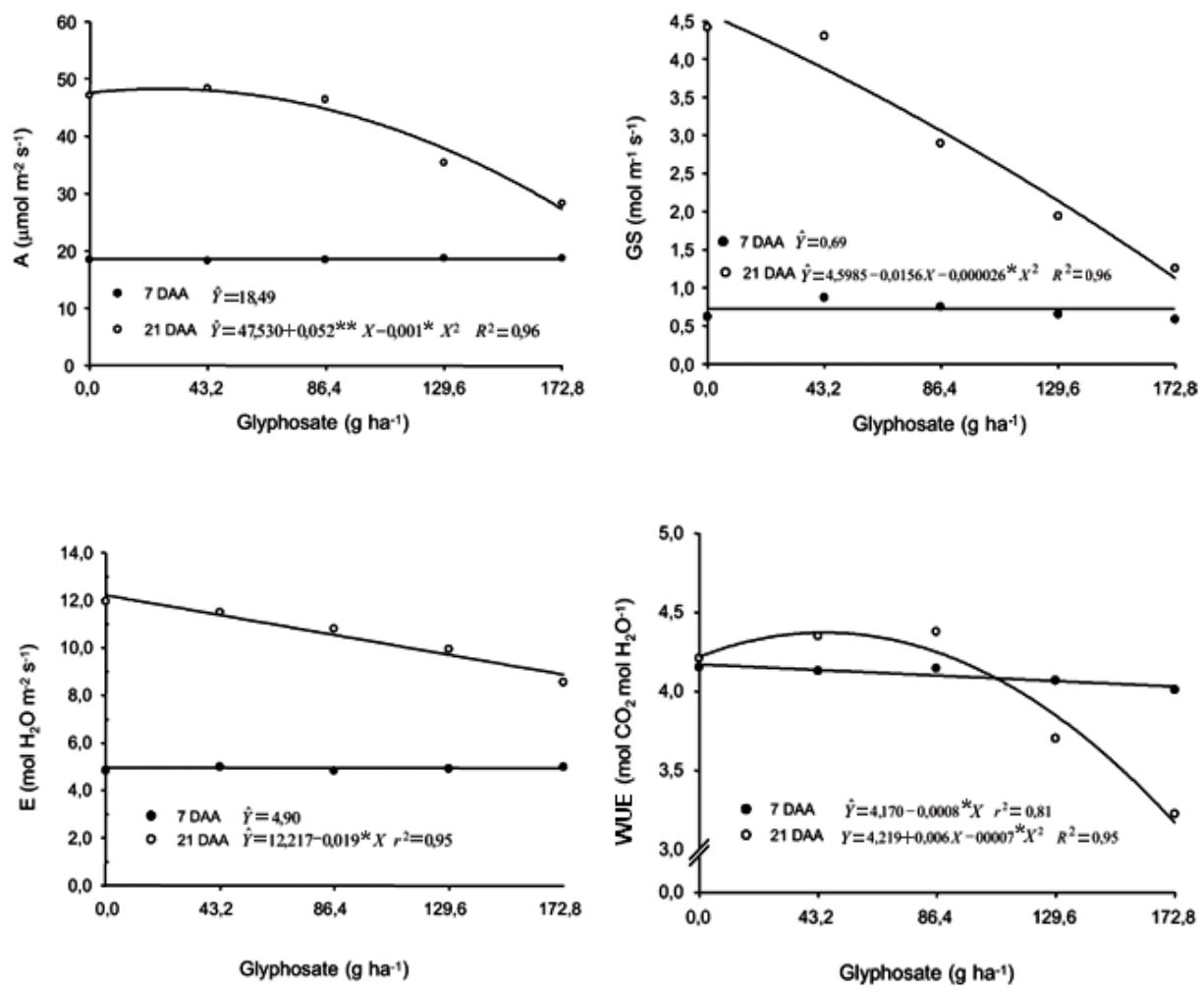

Fig. 1. Physiological parameters of plants of Eucaliptus spp. submitted to increasing doses of glyphosate, 7 and 21 days after application (DAA) of the treatments. Doses are supplied based on commercial formulation containing $360 \mathrm{~g} \mathrm{~L}^{-1}$ of acid equivalent of glyphosate. Source: Machado et al. (2010).

The authors suggest that the smaller dry mass accumulated in treatments under high doses of glyphosate (Figure 2) are due to the higher toxicity caused to plants which resulted in high rates of necrosis and foliar abscission, associated to the lower photosynthesis rate and water use efficiency observed in these treatments 21 DAA of the herbicide. In these terms the authors recommend maximum care when using glyphosate in Eucalyptus plantations aiming to avoid toxicity to the crop and possible plant death, and concluded that the physiological parameters are an essential tool to determine herbicide injury to tree plants, when the evaluations are conducted at the right time after herbicide application. 


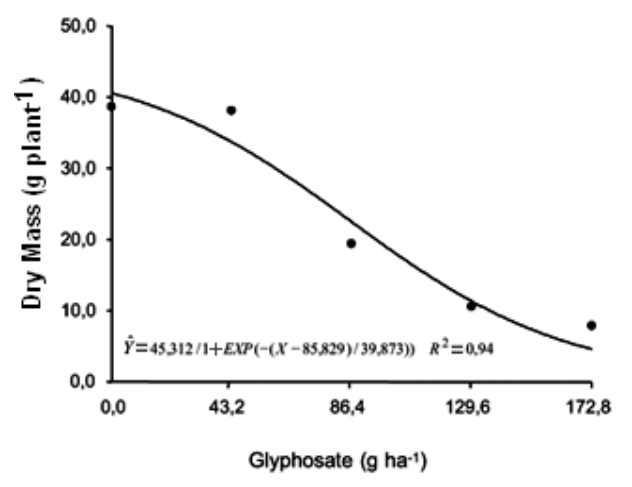

Fig. 2. Dry mass (g plant ${ }^{-1}$ ) of plants of Eucaliptus spp. submitted to increasing doses of glyphosate, 50 days after application (DAA) of the treatments. Doses are supplied based on commercial formulation containing $360 \mathrm{~g} \mathrm{~L}^{-1}$ of acid equivalent of glyphosate. Source:

Machado et al. (2010).

\section{Physiology of weed species}

\subsection{Bidens pilosa, Commelina benghalensis, Brachiaria plantaginea}

B. pilosa, C. benghalensis and B. plantaginea usually are associated in the same community in areas where cassava is grown. There are several implications in controlling these weed species in cassava plantations, and the main one is the lack of herbicides registered to be used in this crop - only four herbicides are registered to be applied in cassava in Brazil. Based on this, it is important to determine the extent of the damage by competition these species are capable of causing to crops, and understand the physiological differences among these weed species.

These weed species were grown alone at densities of 3 plants $\mathrm{m}^{-2}$ (B. pilosa and C. benghalensis) and 6 plants $\mathrm{m}^{-2}$ (B. plantaginea), in soil with moisture constantly maintained at $2 / 3$ of the field capacity. Sixty days after emergence, plants were evaluated in terms of physiological characteristics associated to photosynthesis and water use efficiency.

The stomatal conductance (Gs) did not differ among species, with values around 0,06 mol $\mathrm{m}^{-1} \mathrm{~s}^{-1}$. The stomatal conductance is composed by the small cuticular conductance of the epidermis, and by the stomatal conductance when stomata are open. Because of that, Gs is proportional to stomata number and size. The water vapor exchange between the interior and exterior of the leaf was similar for all species (Table 7). The control of stomatal opening depends upon light availability, $\mathrm{CO}_{2}$ levels in the mesophyll, relative air humidity and water potential inside the plant, as well as other less impacting factors like wind speed, application of growth substances and endogenous rhythms proper of a given species.

Similarly to the Gs, the $E_{a n}$ was also equal among species. This variable is directly related to the water status of the plant and to the dynamics of the water vapor. Even in a leaf with high transpiration rate the relative humidity at the sub-stomatal chamber $\left(E_{a n}\right)$ may be superior to $95 \%$ and the resultant water potential may be around $0 \%$, increasing the vapor exchange with the external environment, which presents water potential highly negative. Under these conditions the instantaneous vapor pressure is the saturation vapor pressure of the temperature of the leaf. In this way the $\mathrm{E}_{\mathrm{an}}$ is controlled by the leaf humidity level and 
temperature, causing changes over both the stomatal conductance of water vapor (Gs) and over the transpiration rate $(\mathrm{E})$.

\begin{tabular}{|c|c|c|c|c|}
\hline \multicolumn{5}{|c|}{ Water Use } \\
\hline Weed Species & $\begin{array}{c}\text { Gs } \\
\left(\mathrm{mol} \mathrm{m}^{-1} \mathrm{~s}^{-1}\right)\end{array}$ & $\begin{array}{c}E_{\text {an }} \\
(\mathrm{mbar})\end{array}$ & $\begin{array}{c}E \\
\left(\mathrm{~mol} \mathrm{H}_{2} \mathrm{O} \mathrm{m}^{-2} \mathrm{~s}^{-1}\right)\end{array}$ & $\begin{array}{c}\text { WUE } \\
\left(\mathrm{mol} \mathrm{CO}_{2} \mathrm{~mol} \mathrm{H}_{2} \mathrm{O}^{-1}\right)\end{array}$ \\
\hline B. pilosa & $0,08 \mathrm{a}$ & $19,90 \mathrm{a}$ & $2,17 \mathrm{a}$ & $0,98 \mathrm{~b}$ \\
\hline C. benghalensis & $0,07 \mathrm{a}$ & $21,57 \mathrm{a}$ & $2,40 \mathrm{a}$ & $1,26 \mathrm{~b}$ \\
\hline B. plantaginea & $0,04 \mathrm{a}$ & $20,30 \mathrm{a}$ & $1,71 \mathrm{~b}$ & $4,85 \mathrm{a}$ \\
\hline CV (\%) & 32,9 & 4,2 & 16,8 & 91,3 \\
\hline \multicolumn{5}{|c|}{ Photosynthesis } \\
\hline Weed Species & $\begin{array}{c}\mathrm{Ci} \\
\left(\mu \mathrm{mol} \mathrm{mol}^{-1}\right)\end{array}$ & $\begin{array}{c}\Delta \mathrm{C} \\
(\mu \mathrm{mol} \mathrm{mol}-1)\end{array}$ & $\begin{array}{l}\mathrm{T}_{\text {leaf }} \\
\left({ }^{\circ} \mathrm{C}\right)\end{array}$ & 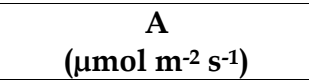 \\
\hline B. pilosa & $303,6 \mathrm{a}$ & $8,30 \mathrm{~b}$ & $30,9 \mathrm{~b}$ & $2,26 \mathrm{~b}$ \\
\hline C. benghalensis & $282,1 \mathrm{~b}$ & $8,17 \mathrm{~b}$ & $34,3 \mathrm{a}$ & $3,07 \mathrm{~b}$ \\
\hline B. plantaginea & $31,2 \mathrm{c}$ & 21,83 a & $35,1 \mathrm{a}$ & $8,44 \mathrm{a}$ \\
\hline CV (\%) & 73,6 & 61,5 & 7,4 & 73,2 \\
\hline
\end{tabular}

Table 7. Parameters associated to the photosynthesis and water use of weed species. In the same variable, means followed by the same letter at the column are not different by the Least Significant Difference (LSD) test at 5\% probability. Source: Aspiazú et al. (2010c).

Bidens pilosa is known by its wide capacity of extracting water from the soil, although it is not highly efficient in water use. This species is capable of keeping high growth rates under soil water potentials in which most of the crops and weed species reached the permanent wilting point, and in some cases this species is benefited by the occurrence of water deficit (Procópio et al., 2004b). B. plantaginea, on the other hand, has a distinct strategy in overcoming severe water stress. While $B$. pilosa is highly efficient in extracting water from soil, $B$. plantaginea is highly efficient in using the amount of water extracted, in part because it is a $\mathrm{C}_{4}$ species. As $B$. plantaginea is capable of keeping high photosynthesis rate even with $\mathrm{CO}_{2}$ concentration in the leaf mesophyll very close to $0 \mathrm{ppm}$, it will allow this species to keep stomata closed for a longer period of time and increase the water use efficiency (WUE). B. plantaginea was superior to the others in terms of water loss as it was able to keep a tighter stomatal opening control. It is probably related to the $\mathrm{C}_{4}$ metabolism of this species and to the lower compensation point of $\mathrm{CO}_{2}$ concentration. As stomata of this species are closed for more time in relation to other species, the amount of water lost by transpiration is reduced. The parameters Gs, $E_{\text {an }}$ and $\mathrm{E}$ are connected to a cost-benefit ratio because the processes of transpiration and $\mathrm{CO}_{2}$ interception from the outside of the leaf only occur when stomata are open. In addition, $\mathrm{E}_{\mathrm{an}}$ is usually reduced in periods of stomatal opening (Aspiazú et al., 2010a).

The higher WUE observed for B. plantaginea is directly related to the $\mathrm{C}_{4}$ carbon cycle in this species and the consequent smaller period of stomatal opening (Table 7). The Ci of the leaf differed among species, and $B$. pilosa showed higher levels of $\mathrm{CO}_{2}$, followed by $C$. benghalensis and B. plantaginea. This is considered a physiological characteristic affected by environmental factors such as water and light availability (Gurevitch et al., 2009). The higher the photosynthesis rate, the higher the amount of $\mathrm{CO}_{2}$ consumed (Table 7), and smaller will be its concentration at the interior of the leaf supposing the stomata are closed (Aspiazú et al., 2010c). The $\mathrm{CO}_{2}$ consumption increases the differences in concentration of this gas 
between the interior and the exterior of the leaf, and in general terms as higher is this gradient $(\triangle \mathrm{C})$, faster the $\mathrm{CO}_{2}$ will enter the leaf in moments of stomatal opening. Because of this, it was also observed that a smaller $\mathrm{Ci}$ also resulted in higher $\Delta \mathrm{C}$.

The leaf temperature $\left(\mathrm{T}_{\text {leaf }}\right)$ is affected by the metabolic rate of the leaf, and in proper conditions this temperature is always $1-3{ }^{\circ} \mathrm{C}$ superior to the environmental temperature around it. In these terms, plant metabolism may be indirectly estimated by the leaf temperature (Attridge, 1990). According to the observed for $\mathrm{Ci}$ and $\triangle \mathrm{C}$, the leaf temperature was lower for $B$. pilosa, because this plant consumed less $\mathrm{CO}_{2}$ per unit of time than the other species, and presented higher $\mathrm{Ci}$ and lower $\triangle \mathrm{C}$ than B. plantaginea (Table 7).

According to the $\mathrm{Ci}, \Delta \mathrm{C}$ and $\mathrm{T}_{\text {leaf, }}$ the photosynthesis rate was higher for $B$. plantaginea in comparison to the other weed species. The photosynthesis and transpiration rates depend upon a constant flux of both $\mathrm{CO}_{2}$ and $\mathrm{O}_{2}$ in and out of the leaves (Messinger et al., 2006).

The authors emphasize that, in general terms, under lower water availability, B. plantaginea tend to be more competitive than $B$. pilosa and $C$. benghalensis due to its superiority at photosynthesis rate and the other physiological parameters studied. On the other hand, $B$. pilosa is capable of keeping high photosynthesis rate even under moderate water stress due to its higher capacity of extracting water from soil - in other words, this species is specialized in avoiding the stress. While B. plantaginea is more efficient in characteristics related to the photosynthesis, i.e. more efficient in use of light, B. pilosa was more efficient in characteristics related to water use.

\subsection{Lolium multiflorum}

Ryegrass (Lolium multiflorum) is an annual winter forage, also extensively used as winter crop, aiming to supply mass for the no-till planting system. This species is distributed in all temperate climate regions of Brazil, especially at the Southern region. By the time of planting, this plant is usually desiccated with the herbicide glyphosate, and recently this species became resistant to this herbicide (Ferreira et al., 2009).

Ferreira et al. (2009) conducted some studies on growth and development of the ryegrass biotype resistant to glyphosate in comparison to the standard susceptible biotype, and concluded that the susceptible biotype accumulates more dry mass than the resistant one. These authors attributed this to the smaller number of tillers at the resistant biotype: while the susceptible biotype presented around 7,2 tillers per plant, the resistant one presented in average 4,4 tillers per plant under the same conditions. Due to this, the number of inflorescences - and as a consequence the number of seeds produced - is smaller at the resistant biotype. Another fact reported by this group of researchers was that the susceptible biotype shifted from the vegetative to the reproductive period 19 days before the resistant, and completed the cycle around 25 days before.

The parameters photosynthesis (A) and water use efficiency (WUE) are usually the main determiners of the predominance of a given species or biotype over the others at the same area, mainly as a function of the environmental stresses to which these plants are subjected to.

As the factors causing this behavior in the resistant biotype were not clear, further work by the same authors went deeper at the physiological causes of these differences. Characteristics related with both the photosynthesis and the water use efficiency at the resistant biotype differed from the susceptible biotype, probably as a consequence of the mechanism conferring resistance to the herbicide glyphosate. The competitive ability of the 
plant affects directly its capacity of using environmental resources, mainly those related to the photosynthesis rate (VanderZee \& Kennedy, 1983; Melo et al., 2006).

When the resistant biotype was put under competition with the susceptible one, the photosynthesis rate was greatly affected. As a consequence, the internal concentration of $\mathrm{CO}_{2}$ in the leaf is increased because its consumption by photosynthesis was reduced (Figure 3). Considering the previously discussed fact that the stomatal opening is related with both the internal $\mathrm{CO}_{2}$ concentration of the leaf (in smaller degree) and to the level of light available (in higher degree), it is hypothesized by the authors that under field conditions there would be a smaller period of stomatal opening for the resistant biotype, when under competition with the susceptible one, resulting in smaller dry mass accumulation.
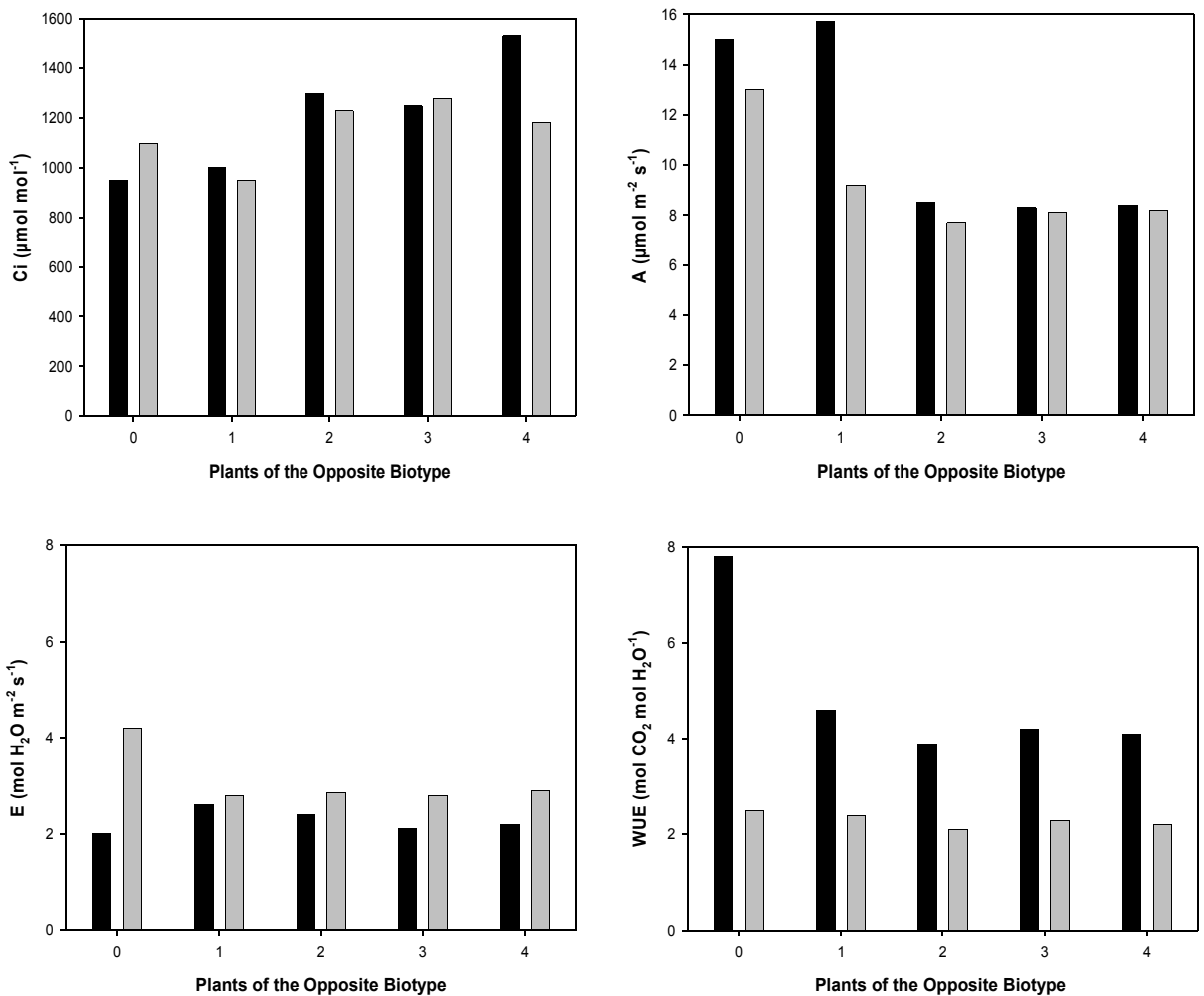

Fig. 3. Physiological parameters measured at biotypes of Lolium multiflorum resistant (D) or susceptible (㜻) to the herbicide glyphosate. Source: Ferreira et al. (2009).

Under low competition levels, the resistant biotype is more efficient in water use than the susceptible one (Figure 3). However, this biotype becomes less efficient in water use as the competition level is increased. Some studies show that the resistant biotype accumulates less dry mass because the period of stomatal opening is smaller to avoid losing excessive water, and as a consequence small amounts of $\mathrm{CO}_{2}$ move from the external environment to the interior of the leaf. On the other hand, a possible smaller speed of water movement from 
roots to shoots would limit the water loss to that contained at the sub-stomatal chamber during the period of stomatal opening, which would make the resistant biotype more efficient in water use at the expense of smaller dry mass accumulation capabilities.

The most probable reason for the resistant biotype to be more efficient at the water use is a supposed smaller efficiency in water absorption or translocation, as well as the smaller period of stomatal opening. It is highlighted, however, that a higher WUE does not guarantee that this biotype has any physiological advantage over the susceptible one under low competition levels. As previously presented, plants of B. pilosa are highly efficient in extracting water from soil, but present relatively low WUE (Procópio et al., 2004b).

\subsection{Echinochloa crusgalli}

Barnyardgrass (Echinochloa crusgalli) infest rice fields worldwide being rarely found in shaded places. This species is adapted to anaerobic environments, being capable of germinating even under $10 \mathrm{~cm}$ of water (Concenço et al., 2009). The high number of seeds produced increases both its importance as a weed and the survival of the species. In addition, this species present $\mathrm{C}_{4}$ carbon cycle while rice is a $\mathrm{C}_{3}$ species.

The competition for light between rice and barnyardgrass plants occur when the latter grow more than the former, shading the plants of the crop and reducing both the quantity and the quality of the light received by the rice plants (Concenço et al., 2009). Several studies showed that taller plants present superior ability of causing interference in crops, mainly in terms of amount of light intercepted. Barnyardgrass plants are usually twice the size of the current rice varieties when mature.

Although relatively easy to control, barnyardgrass plants are becoming a more serious problem because there are several biotypes resistant to herbicides around the world. In Brazil the main problem is the occurrence of several biotypes resistant to the herbicide quinclorac. As the chemical control method becomes inefficient in controlling this species, the physiology of the plant should be explored and understood to allow application of management practices which will allow a cultural suppression of the occurrence of this weed species.

Preliminary works showed that there are variations among biotypes in terms of growth rate, and hypothesized that this was probably related to the physiology of the plant. Later studies by Concenço et al. (2009) supplied some light on the physiological behavior of these biotypes in terms of characteristics associated to the photosynthesis and growth rates. At Table 8 is presented a comparison between a susceptible and a resistant biotype to the herbicide quinclorac, in terms of variables associated to the photosynthesis.

In relation to the variables associated to the photosynthesis, differences between biotypes were not observed (Table 8). In relation to the increasing at the competition intensity, it is possible to conclude that both biotypes are similar but the susceptible biotype was generally more affected than the resistant one under high competition levels, in comparison to the control with no competition. More vigorous plants are capable to cover the available space faster and avoid access of the less vigorous plants to light.

At Table 9 it is supplied a comparison between a susceptible and a resistant biotype to the herbicide quinclorac in terms of variables associated to the water use efficiency. Also, differences were not found. The authors concluded that unlike Lolium multiflorum biotypes which differ greatly in terms of physiologic parameters and competitive ability, barnyardgrass biotypes resistant and susceptible to the herbicide quinclorac present similar 
performance in terms of physiology and biomass accumulation, and the probable mutation responsible for conferring resistance to the herbicide did not affect the environmental fitness of the biotype at significant levels.

\begin{tabular}{|c|c|c|c|}
\hline $\begin{array}{l}\text { Plants under } \\
\text { Competition }\end{array}$ & Resistant Biotype & Susceptible Biotype & $\begin{array}{c}\text { Difference between } \\
\text { Biotypes }\end{array}$ \\
\hline & \multicolumn{3}{|c|}{ Sub-Stomatal $\mathrm{CO}_{2}$ Concentration - $\mathrm{Ci}(\mu \mathrm{mol} \mathrm{mol}-1)$} \\
\hline $\mathbf{1}$ & $23,4 \mathrm{~b}$ & $18,1 \mathrm{c}$ & $+5,3 \mathrm{~ns}$ \\
\hline 2 & $29,7 \mathrm{~b}$ & $29,3 \mathrm{bc}$ & $+0,4 \mathrm{~ns}$ \\
\hline 3 & $36,5 \mathrm{ab}$ & $33,6 \mathrm{bc}$ & $+2,9 \mathrm{~ns}$ \\
\hline 4 & $43,2 \mathrm{ab}$ & $48,5 \mathrm{ab}$ & $-5,3$ ns \\
\hline \multirow[t]{2}{*}{5} & $55,3 \mathrm{a}$ & $60,2 \mathrm{a}$ & $-4,9 \mathrm{~ns}$ \\
\hline & \multicolumn{3}{|c|}{ Photosynthesis Rate - A $\left(\mu \mathrm{mol} \mathrm{m}^{-2} \mathrm{~s}^{-1}\right)$} \\
\hline $\mathbf{1}$ & $23,2 \mathrm{a}$ & $23,0 \mathrm{a}$ & $+0,2 \mathrm{~ns}$ \\
\hline 2 & $19,4 \mathrm{ab}$ & $22,2 \mathrm{ab}$ & $-2,8 \mathrm{~ns}$ \\
\hline 3 & $21,0 \mathrm{ab}$ & $20,8 \mathrm{abc}$ & $+0,2 \mathrm{~ns}$ \\
\hline 4 & $21,5 \mathrm{ab}$ & $17,9 \mathrm{bc}$ & $+3,6 \mathrm{~ns}$ \\
\hline 5 & $18,1 \mathrm{~b}$ & $16,8 \mathrm{c}$ & $+1,3 \mathrm{~ns}$ \\
\hline
\end{tabular}

Table 8. Physiological parameters associated to the photosynthesis in barnyardgrass (Echinochloa crusgalli) biotypes, resistant or susceptible to the herbicide quinclorac. Means followed by the same letter at the column, inside each variable, are not significantly different by the DMRT test at 5\% of probability. Source: Concenço et al. (2009).

\begin{tabular}{|c|c|c|c|}
\hline $\begin{array}{l}\text { Plants under } \\
\text { Competition }\end{array}$ & Resistant Biotype & Susceptible Biotype & $\begin{array}{c}\text { Difference between } \\
\text { Biotypes }\end{array}$ \\
\hline & \multicolumn{3}{|c|}{ Transpiratory Rate - E $\left(\mathrm{mol} \mathrm{H}_{2} \mathrm{O} \mathrm{m}^{-2} \mathrm{~s}^{-1}\right)$} \\
\hline 1 & $1,86 \mathrm{a}$ & $1,97 \mathrm{a}$ & $-0,11 \mathrm{~ns}$ \\
\hline 2 & $1,84 \mathrm{a}$ & $1,78 \mathrm{ab}$ & $+0,06 \mathrm{~ns}$ \\
\hline 3 & $1,65 \mathrm{a}$ & $1,70 \mathrm{ab}$ & $-0,05 \mathrm{~ns}$ \\
\hline 4 & $1,72 \mathrm{a}$ & $1,35 \mathrm{~b}$ & $+0,37 \mathrm{~ns}$ \\
\hline \multirow[t]{2}{*}{5} & $1,39 \mathrm{a}$ & $1,29 \mathrm{~b}$ & $+0,10 \mathrm{~ns}$ \\
\hline & \multicolumn{3}{|c|}{ Water Use Efficiency - WUE $\left(\mu \mathrm{mol} \mathrm{CO} \mathrm{CO}_{2} \mathrm{~mol} \mathrm{H}_{2} \mathrm{O}^{-1}\right)$} \\
\hline 1 & $13,1 \mathrm{a}$ & $11,7 \mathrm{a}$ & $+1,4 \mathrm{~ns}$ \\
\hline 2 & $10,5 \mathrm{a}$ & $12,5 \mathrm{a}$ & $-2,0 \mathrm{~ns}$ \\
\hline 3 & $12,7 \mathrm{a}$ & $12,2 \mathrm{a}$ & $+0,50 \mathrm{~ns}$ \\
\hline 4 & $12,5 \mathrm{a}$ & $13,2 \mathrm{a}$ & $-0,70 \mathrm{~ns}$ \\
\hline 5 & $13,0 \mathrm{a}$ & $13,0 \mathrm{a}$ & $0 \mathrm{~ns}$ \\
\hline
\end{tabular}

Table 9. Physiological parameters associated to the water use in barnyardgrass (Echinochloa crusgalli) biotypes, resistant or susceptible to the herbicide quinclorac. Means followed by the same letter at the column, inside each variable, are not significantly different by the DMRT test at $5 \%$ of probability. Source: Concenço et al. (2009).

\section{Final comments and conclusions}

The weed species present distinct strategies to avoid stresses aiming to keep high rates of physiological metabolism. As example, B. plantaginea is highly efficient at the use of water; 
B. pilosa is not efficient in using water but is capable of extracting this resource from soil at water potentials where most other weeds are reaching the permanent wilting point, and $C$. benghalensis produces aerial and subterranean seeds, being also capable of propagating vegetatively.

Biotypes of weeds resistant to herbicides, like Echinochloa crusgalli resistant to quinclorac and Lolium multiflorum resistant to glyphosate, may present different abilities to those at the susceptible biotype. These differences are related to morphophysiological changes caused by the mechanism which confers resistance to the herbicide, and the physiological parameters associated to the photosynthesis rate and water use efficiency are highly effective in pointing out these discrepancies among plant biotypes when they are present, and probably also useful for differentiating plant ecotypes of the same species. Thus, the measurement of physiological parameters associated to photosynthesis and water use present a wide range of applicabilities, and many of them are currently not fully explored.

Some weed species or biotypes of weed species are so poor competitors against certain crops, that it is unnecessary to eliminate them from the field when they occur at low densities, if all other developmental factors (light, water, $\mathrm{CO}_{2}$ ) are supplied at minimum required levels for crop development. In fact, some low competitive weed species are recognized by some crops before the competition starts, and these crops are able to increase their metabolism as an answer to the presence of that given weed species, growing faster while trying to avoid the competition with that weed species. The presence of low infestation of such weed species is hypothesized to result in positive effect over the crop competitiveness; maybe not increasing yield, but increasing crop capacity to compete against other weeds.

In relation to the application of chemicals for weed management inside crop fields and tree plantations, it is advised to observe the optimal time after application when symptoms of phytotoxicity are present to avoid mis-determining a lower impact than the real from the herbicide and dose over the crops. In this scenario, physiological parameters are more efficient than directly quantified variables, also supplying results faster.

In general terms, more attention should be given to the behavior of physiological parameters in crops and weed species when they are submitted to some type of stress. At this chapter the possibility of using physiological parameters in determining the effects of competition between plant species over each one of the species involved, as well as a tool to describe the impact of a given herbicide treatment, were illustrated. However, these parameters are suitable for inferences in many other types of applications not discussed at this chapter.

\section{References}

Albuquerque, J.A.A., Sediyama, T., Silva, A.A., Carneiro, J.E.S., Cecon, P.R. \& Alves, J.M.A. (2008). Interferência de plantas daninhas sobre a produtividade da mandioca (Manihot esculenta). Planta Daninha, Vol.26, No.2, (April/June 2008), pp.279-289, ISSN 0100-8358.

Aliyev, J.A. (2010). Photosynthesis, photorespiration and productivity of wheat and soybean genotypes. Proceedings of ANAS (Biological Sciences), Vol.65, No.5/6, pp.7-48.

Aspiazú, I., Concenço, G., Galon, L., Ferreira, E.A. \& Silva, A.F. (2008). Relação colmos/folhas de biótipos de capim-arroz em condição de competição. Revista Trópica, Vol.2, No.1, pp.22-30, ISSN 1982-4831. 
Aspiazú, I., Sediyama, T., Ribeiro Jr., J.I., Silva, A.A., Concenço, G., Ferreira, E.A., Galon, L., Silva, A.F., Borges, E.T. \& Araujo, W.F. (2010a). Water use efficiency of cassava plants under competition conditions. Planta Daninha, Vol.28, No.4, (December 2010), pp.699-703, ISSN 0100-8358.

Aspiazú, I., Sediyama, T., Ribeiro Jr., J.I., Silva, A.A., Concenço, G., Ferreira, E.A., Galon, L., Silva, A.F., Borges, E.T. \& Araujo, W.F. (2010b). Photosynthetic activity of cassava plants under weed competition. Planta Daninha, Vol.28, pp.963-968, ISSN 01008358. Special Number.

Aspiazú, I., Sediyama, T., Ribeiro Jr., J.I., Silva, A.A., Concenço, G., Galon, L.V., Ferreira, E.A., Silva, A.F., Borges, E.T. \& Araujo, W.F. (2010c). Eficiéncia fotosintética y de uso del agua por malezas. Planta Daninha, Vol.28, No.1, pp.87-92, ISSN 0100-8358.

Attridge, T.H. (1990). The natural environment, In: Light and Plant Responses, Attridge, T.H. (Ed.), pp.1-5, Edward Arnold, ISBN 978-052-1427-48-7, London, England.

Azania, C.A.M., Rolim, J.C., Casagrande, A.A., Lavorenti, N.A. \& Azania, A.A.P.M. (2005). Seletividade de herbicidas. II - Aplicação de herbicidas em pós-emergência inicial e tardia da cana-de-açúcar na época das chuvas. Planta Daninha, Vol.23, No.4, (October/December 2005), pp. 669-675, ISSN 0100-8358.

Ballaré, C.L., Scopel, A.L. \& Sánchez, R.A. (1990). Far-red radiation reflected from adjacent leaves an early signal of competition in plant canopies. Science, Vol. 247, No.4940, (January 1990), pp. 329-332, ISSN 0036-8075.

Bianchi, M.A., Fleck, N.G., Lamego, F.P. \& Agostinetto, D. (2010). Papéis do arranjo de plantas e do cultivar de soja no resultado da interferência com plantas competidoras. Planta Daninha, Vol.28, pp.979-991, ISSN 0100-8358. Special Number.

Ceccon, G. (2007. Milho safrinha com solo protegido e retorno econômico em Mato Grosso do Sul. Revista Plantio Direto, Ano16, No.97, (Janeiro/Fevereiro 2007), pp.17-20, ISSN 16778081.

Concenço, G., Noldin, J.A., Eberhardt, D.S. \& Galon, L. (2009). Resistência de Echinochloa sp. ao herbicida quinclorac, In: Resistência de Plantas Daninhas a Herbicidas no Brasil, Agostinetto, D. \& Vargas, L. (Eds.), pp.309-350, Berthier, ISBN 978-858-9873-92-5, Passo Fundo, Brazil.

Da Matta, F.M., Loos, R.A., Rodrigues, R. \& Barros, R. (2001). Actual and potential photosynthetic rates of tropical crop species. Revista Brasileira de Fisiologia Vegetal, Vol.13, No.1, (Abril 2001), pp.24-32, ISSN 0103-3131.

Dutton, R.G., Jiao, J., Tsujita, J. \& Grodzinski, B. (1988). Whole plant $\mathrm{CO}_{2}$ exchange measurements for non destructive estimation of growth. Plant Physiology, Vol.86, No.2, (February 1988), pp.355-358, ISSN 0032-0889.

Ferreira, E.A., Concenço, G., Vargas, L., Silva, A.A. \& Galon, L. (2009). Resistência de Lolium multiflorum ao glyphosate, In: Resistência de Plantas Daninhas a Herbicidas no Brasil, Agostinetto, D. \& Vargas, L. (Eds.), pp.271-289, Berthier, ISBN 978-858-9873-92-5, Passo Fundo, Brazil.

Fleck, N.G., Agostinetto, D., Galon, L. \& Schaedler, C.E. (2008). Competitividade relativa entre cultivares de arroz irrigado e biótipo de arroz-vermelho. Planta Daninha, Vol.26, No.1, (January/March 2008), pp.101-111, ISSN 0100-8358.

Floss, E.L. (2008). Fisiologia das Plantas Cultivadas (4th Ed.), Universidade de Passo Fundo, ISBN 978-857-5156-41-4, Passo Fundo, Brazil. 
Galon, L., Agostinetto, L., Moraes, P.V.D., Dal Magro, T., Panozzo, L.E., Brandolt, R.R. \& Santos, L.S. (2007). Níveis de dano econômico para decisão de controle de capimarroz (Echinochloa spp.) em arroz irrigado (Oryza sativa). Planta Daninha, Vol.25, No.4, (October/December 2007), pp.709-718, ISSN 0100-8358.

Galon, L., Ferreira, F.A., Silva, A.A., Concenço, G., Ferreira, E.A., Barbosa, M.H.P., Silva, A.F., Aspiazú. I., França, A.C. \& Tironi, S.P. (2010). Influência de herbicidas na atividade fotossintética de genótipos de cana-de-açúcar. Planta Daninha, Vol.28, No.3, pp.591-597, ISSN 0100-8358.

Gurevitch, J., Scheiner, S.M. \& Fox, G.A. (2009). Ecologia Vegetal (2nd Ed.), Artmed, ISBN 978853-6319-18-6, Porto Alegre, Brazil.

Humble, G.D. \& Hsiao, T.C. (1970). Light-dependent influx and efflux of potassium of guard cells during stomatal opening and closing. Plant Physiology, Vol.46, No.3, (September 1970), pp.483-487, ISSN 0032-0889.

Hutmacher, R.B. \& Krieg, D.R. (1983). Photosynthetic rate control in cotton. Plant Physiology, Vol.73, No.3, (November 1983), pp.658-661, ISSN 0032-0889.

Kirschbaum, M.U.F. \& Pearcy, R.W. (1988). Gas exchange analysis of the relative importance of stomatal and biochemical factors in photosynthetic induction in Alocasia macrorrhiza. Plant Physiology, Vol.86, No.3, (March 1988), pp.782-785, ISSN 00320889.

Larcher, W. (2004). Ecofisiologia Vegetal, Rima, ISBN 858-655-2038, São Paulo, Brazil.

Long, S.P. \& Bernacchi, C.J. (2003). Gas exchange measurements, what can they tell us about the underlying limitations to photosynthesis? Procedures and sources of error. Journal of Experimental Botany, Vol.54, No.392, (November 2003), pp.2393-2401, ISSN 0022-0957.

Machado, A.F.L., Ferreira, L.R., Santos, L.D.T., Ferreira, F.A., Viana, R.G., Machado, M.S.V. \& Freitas, F.C.L. (2010). Eficiência fotossintética e uso da água em plantas de eucalipto pulverizadas com glyphosate. Planta Daninha, Vol.28, No.2, (April/June 2010), pp.319-327, ISSN 0100-8358.

Melo, P.T.B.S., Schuch, L.O.B., Assis, F. \& Concenço, G. (2006). Comportamento de populações de arroz irrigado em função das proporções de plantas originadas de sementes de alta e baixa qualidade fisiológica. Revista Brasileira de Sementes, Vol.12, No.1, pp.37-43, ISSN 0101-3122.

Merotto Jr., A., Fischer, A.J. \& Vidal, R.A. (2009). Perspectives for using light quality knowledge as an advanced ecophysiological weed management tool. Planta Daninha, Vol.27, No.2, (April/June 2009), pp.407-419, ISSN 0100-8358.

Messinger, S.M., Buckley, T.N. \& Mott, K.A. (2006). Evidence for involvement of photosynthetic processes in the stomatal response to $\mathrm{CO}_{2}$. Plant Physiology, Vol.140, No.2, (February 2006), pp.771-778, ISSN 0032-0889.

Naves-Barbiero, C.C., Franco, A.C., Bucci, S.J. \& Goldstein, G. (2000). Fluxo de seiva e condutância estomática de duas espécies lenhosas sempre-verdes no campo sujo e cerradão. Revista Brasileira de Fisiologia Vegetal, Vol.12, No.1, (Abril 2000), pp.119134, ISSN 0103-3131.

Procópio, S.O., Santos, J.B., Silva, A.A., Martinez, C.A. \& Werlang, R.C. (2004a). Características fisiológicas das culturas de soja e feijão e de três espécies de plantas daninhas. Planta Daninha, Vol.22, No.2, (April/June 2004), pp.211-216, ISSN 01008358 . 
Procópio, S.O., Santos, J.B., Silva, A.A., Donagemma, G.K. \& Mendonça, E.S.V. (2004b). Ponto de murcha permanente de soja, feijão e plantas daninhas. Planta Daninha, Vol.22, No.1, (January/March 2004), pp.35-41, ISSN 0100-8358.

Pystina, N.V. \& Danilov, R.A. (2001). Influence of light regimes on respiration, activity of alternative respiratory pathway and carbohydrates content in mature leaves of Ajuga reptans L. Revista Brasileira de Fisiologia Vegetal, Vol.13, No.3, (Dezembro 2001), pp. 285-292, ISSN 0103-3131.

Radosevich, S.R., Holt, J.S. \& Ghersa, C.M. (2007). Ecology of Weeds and Invasive Plants: Relationship to Agriculture and Natural Resource Management (3rd Ed.), John Wiley \& Sons, ISBN 978-047-1767-79-4, Hoboken, USA.

Santos, J.B., Procópio, S.O., Silva, A.A. \& Costa, L.C. (2003). Captação e aproveitamento da radiação solar pelas culturas da soja e do feijão e por plantas daninhas. Bragantia, Vol.62, No.1, (Janeiro/Abril 2003), pp.147-153, ISSN 0006-8705.

Severino, F.J. (2005). Supressão da Infestação de Plantas Daninhas pelo Sistema de Produção de Integração Lavoura-Pecuária. 113p. Thesis (Doctorate) - Escola Superior de Agricultura "Luiz de Queiroz", Universidade de São Paulo, Piracicaba.

Sharkey, T.D. \& Raschke, K. (1981). Effect of light quality on stimatal opening in leaves of Xanthium strumarium. Plant Physiology, Vol.68, No.5, (November 1981), pp.11701174, ISSN 0032-0889.

Silva, A.A., Ferreira, F.A., Ferreira, L.R. \& Santos, J.B. (2007). Biologia de plantas daninhas, In: Tópicos em Manejo de Plantas Daninhas, Silva, A.A. \& Silva, J.F., pp.17-61, Universidade Federal de Viçosa, ISBN 978-857-2692-75-5, Viçosa, Brazil.

Tambuci, E.A., Bort, J. \& Araus, J.L. (2011). Water use efficiency in C3 cereals under mediterranean conditions: a review of some physiological aspects. Options Méditerranéennes, Series B, No.57, pp.189-203, ISSN 1016-1228.

Taylor Jr., G.E. \& Gunderson, C.A. (1986). The response of foliar gas exchange to exogenously applied ethylene. Plant Physiology, Vol.82, No.3, (November 1986), pp.653-657, ISSN 0032-0889.

Tuffi Santos, L.D.T., Ferreira, F.A., Machado, A.F.L., Ferreira, L.R. \& Santos, B.F.S. (2010). Glyphosate em eucalipto: formas de contato e efeito do herbicida sobre a cultura, In: Manejo Integrado de Plantas Daninhas na Cultura do Eucalipto, Ferreira, L.R., Machado, A.F.L., Ferreira, F.A. \& Santos, L.D.T. (Eds.), pp.91-116, Universidade Federal de Viçosa, ISBN 978-857-2693-76-9, Viçosa, Brazil.

Vanderzee, D. \& Kennedy, R.A. (1983). Development of photosynthetic activity following anaerobic germination in rice-mimic grass (Echinochloa crus-galli var. oryzicola). Plant Physiology, Vol.73, No.2, (October 1983), pp.332-339, ISSN 0032-0889. 


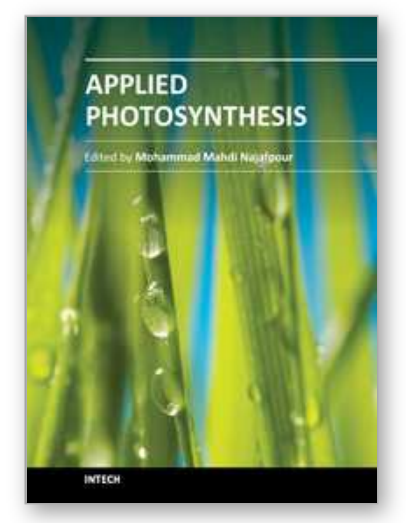

\author{
Applied Photosynthesis \\ Edited by Dr Mohammad Najafpour
}

ISBN 978-953-51-0061-4

Hard cover, 422 pages

Publisher InTech

Published online 02, March, 2012

Published in print edition March, 2012

Photosynthesis is one of the most important reactions on Earth, and it is a scientific field that is intrinsically interdisciplinary, with many research groups examining it. This book is aimed at providing applied aspects of photosynthesis. Different research groups have collected their valuable results from the study of this interesting process. In this book, there are two sections: Fundamental and Applied aspects. All sections have been written by experts in their fields. The book chapters present different and new subjects, from photosynthetic inhibitors, to interaction between flowering initiation and photosynthesis.

\title{
How to reference
}

In order to correctly reference this scholarly work, feel free to copy and paste the following:

Germani Concenço, Ignacio Aspiazú, Evander A. Ferreira, Leandro Galon and Alexandre F. da Silva (2012). Physiology of Crops and Weeds Under Biotic and Abiotic Stresses, Applied Photosynthesis, Dr Mohammad Najafpour (Ed.), ISBN: 978-953-51-0061-4, InTech, Available from: http://www.intechopen.com/books/appliedphotosynthesis/physiology-of-crops-and-weeds-under-biotic-and-abiotic-stresses

\section{INTECH}

open science | open minds

\section{InTech Europe}

University Campus STeP Ri

Slavka Krautzeka 83/A

51000 Rijeka, Croatia

Phone: +385 (51) 770447

Fax: +385 (51) 686166

www.intechopen.com

\section{InTech China}

Unit 405, Office Block, Hotel Equatorial Shanghai

No.65, Yan An Road (West), Shanghai, 200040, China

中国上海市延安西路65号上海国际贵都大饭店办公楼 405 单元

Phone: +86-21-62489820

Fax: $+86-21-62489821$ 
(C) 2012 The Author(s). Licensee IntechOpen. This is an open access article distributed under the terms of the Creative Commons Attribution 3.0 License, which permits unrestricted use, distribution, and reproduction in any medium, provided the original work is properly cited. 